\author{
удК 355.43 \\ DOI: https://doi.org/10.18485/fb_iss.2020.1.ch3
}

\title{
СТРАТЕГИЈСКО МИШЉЕЊЕ И КРЕАЦИЈА РЕШЕЊА
}

\author{
проф. др Петар Станојевић ${ }^{1}$
}

\section{Апстракт}

У овом раду пажња се посвећује томе како креирати (осмислити) успешну стратегију или барем ону која има мањи ризик од неуспеха. За креирање стратегија неопходно је стратегијско мишљење, које је по својој природи специфично. Циљ рада је да се да преглед метода и техника стратегијског мишљења, тачније подршке стратегијском мишљењу, као и начина и могућности њихове примене. Такође су, на основама познатих, развијени алгоритми примене стратегијског мишљења и планирања. Анализиране су одлике, начини и предуслови стратегијског мишљења. Стратегијско мишљење је доведено у контекст са стратегијским планирањем. Већина активности стратегијског планирања не може се реализовати без стратегијског осмишљавања. До данас је осмишљено и ствара се мноштво погодних поступака, метода и техника уз помоћ којих се олакшава и структурира процес стратегијског мишљења. Део познатих метода и техника је приказан у раду путем схема, алгоритама, графикона или вербалних описа. Методе и технике су приказане, већином, на реалним примерима. Неке од метода и техника стратегијског мишљења могу се применити за више фаза или активности стратегијског планирања. Анализиране су њихове предности и мане, као и могућности примене. Посебна пажња посвећена је методологији и техникама дефинисања визије и мисије организације.

Кључне речи: стратегија, стратегијско мишљење, методе, технике

\section{УВоД}

Много се пише и говори о томе шта је стратегија, шта све подразумева и каква може да буде, а мање о томе како је креирати (осмислити). Поготову се мало говори о томе како осмислити успешну стратегију или барем ону која има мањи ризик од неуспеха. Дефиниције стратегије укључују у себи појмове: јасног циља, плана, употребе ресурса, временског ограничења и наравно успеха или стања које нас издваја од других у позитивном смислу. Нису сви доносиоци одлука доживели

\footnotetext{
1 Ванредни професор, Факултет Безбедности, Универзитет у Београду. Е-пошта: petstano45@gmil.com
} 
„просвећење“ након кога су тријумфовали, као на пример Александар Македонски код Гугамеле, Темистокле код Саламине, Кутузов после Бородинске битке или Војвода Мишић у Колубарској бици. За већину процес креирања стратегија представља дуготрајан и мукотрпан интелектуални процес, увек са непознатим исходом, посебно када се дође до имплементације. Увек се морала повезати политика преко стратегије до тактике, али и по потреби се веза морала стварати и у супротном правцу. Да би се олакшало креирање стратегија и истовремено постигао пожељан исход процеса, данас је осмишљено и осмишљава се мноштво погодних поступака, метода и техника.

\section{СТРАТЕГИЈСКО МИШЉЕЊЕ}

Стратегијско мишљење би се могло одредити као „скуп идеја и размишљања које помажу доносиоцима одлука да схвате ширу слику и да се заштите од негативног утицаја сувишног обраћања пажње на непотребне детаље. То је флуидан процес којим се генерише увид (анализа), алтернативе (опције) и пробоји (скуп акција nрим. aym.) којима се организација покреће унапред у правцу несигурног, али изазовног циља у истом таквом окружењу“. ${ }^{2}$ Оперативно и стратегијско мишљење се разликују по својим особинама, од којих су главне дате у табели $1 .{ }^{3}$

Табела 1. Упоредни приказ особина оперативног и стратегијског мишљења

\begin{tabular}{|c|c|}
\hline Оперативно мишљење & Стратегијско мишљење \\
\hline линеарно (једносмерно) & итеративно и непредвидиво \\
\hline дедуктивно & индуктивно и интуитивно \\
\hline $\begin{array}{c}\text { програмирано (засновано на } \\
\text { процедурама) }\end{array}$ & неодређено и нејасно \\
\hline границе су јасне & провоцира нервозу и укључује ризик \\
\hline
\end{tabular}

Извор: Адаптација аутора

Стратешко мишљење може, али не мора бити последица детаљно разрађеног процеса. Извесна процедура помаже да се смањи вероватноћа грешке, али се мора водити рачуна да се тиме не угуши креативност. Овај начин мишљења је немогућ без сталне анализе ситуације како би се препознале претње, али и прилике. Такође, немогуће је бити стратег, а немати способност маштања, предвиђања будућности и креирања сценарија („шта би било кад би било“). Често се стратегијско мишљење пореди са „погледом са висине“ или „погледом из хеликоптера“, односно оним који има већи обухват, способност да у маси издвоји важне детаље, могућност да брзо промени смер и правац, које омогућава и

2 Tony Grundy, Laura Brown, Be your own Strategy Consultant, Thomson Learning, London, 2004, p. 5.

3 Ibid. 
прикривање и изненађење, које има снагу да доведе до коначне одлуке и које је флексибилно и разноврсно, неки кажу и лукаво.

Нивои примене стратегијског мишљења могу бити различити: државни, војни, секторски, компанијски, пословне функције, на нивоу пројекта и на нивоу појединца и његових пословних и животних потреба (у даљем тексту, да се не би набрајали сви ови нивои, користиће се реч организација која може садржати сваки будући појам). Проистиче из овога да свако може да буде стратегијски „мислилац“.

За стратегијско мишљење се каже да је тешко, и то обично из следећих разлога: мањка знања и знања о техникама, непостојања процеса, нејасне користи, нејасноћа, неизвесности и неодређености, неједнозначности, тешкоћа у јасном одређивању циљева, апстрактности, недостатка времена и слично. Претходно, онемогућава свима да буду успешни стратегијски мислиоци. Очито је само да они који не буду стратегијски размишљали хрле у ранију или каснију пропаст.

\section{Предуслови успешног стратегијског мишљења}

Стратегија се увек креира за неко будуће време и будуће догађаје, и с тим у вези увек је повезана са одређеним нивоом неодређености и неизвесности. Самим тим, свака стратегија носи одређени ниво ризика од погрешних решења и погрешне примене. Због тога се о успешности стратегије може говорити тек по њеној примени. Уколико нису испоштовани предуслови у креацији решења, вероватноћа успеха је мања.

Предуслови за креирање успешних стратегија или успешно стратегијско мишљење би се могли испунити уколико се испоштује одређени редослед корака:

- Прикупљање и анализа релевантних података и информација (обезбеђење потребних и довољних улаза);

- Дефинисање пожељне визије и мисије и на основу њих јасних циљева и приоритета;

- Спровођење структуираног процеса креирања могућих решења (опција) уз коришћење адекватних метода и техника како би се обезбедило добијање јасних и употребљивих резултата;

- Доношење одлуке на основу избора између понуђених опција (уколико се не могу јасно издвојити најбоља решења и овде се препоручује примена одређених метода и техника);

- Израда реалистичног плана имплементације (првенствено с обзиром на време и ресурсе, али и утицај стејкхолдера).

Да би се смањио ниво неодређености и неизвесности, пожељно је поседовати информације о плановима и намерама непријатеља или конкуренције. То, међутим, не мора бити довољно за предузимање успешних акција. ${ }^{4}$ Свака

4 Примера ради, Стаљин је преко Зоргеа знао детаље напада Немачке на СССР и ништа посебно није предузео. 
стратегија мора се заснивати на добром познавању ситуације, како прошлих, тако и оне актуелне. Информације о трендовима и развоју у областима од интереса су предуслов без кога се, такође, не може. Извесна стратегија може бити подељена и на подстратегије. Често се на тај начин боље креирају парцијална решења, која је потребно онда уклопити у ширу слику. Добар пример подстратегије може бити стратегија одређеног пројекта унутар стратегије неке компаније. Постојање структурираног процеса уз методе и технике може убрзати процес креирања стратегије и довести до бољих решења. Ова два параметра (време и успешност) обично се сматрају најпроблематичнијим у одређивању стратегија. Не треба заборавити ни јак утицај „бихевиоралних“ фактора на свако одлучивање, што значи да је корисно прикупити информације о доносиоцима одлука или утицајним чиниоцима (stakeholders).

На слици 1 дата је пирамида бихејвиоралних или прецизније људских интереса, понашања, психолошких профила и сл. коју сви заједно, али са различитим интензитетом, квалитетом и у различитим моментима утичу на доношење стратегије.

На дну се налази скуп прећутних и несвесних људских аспирација. Њих има више

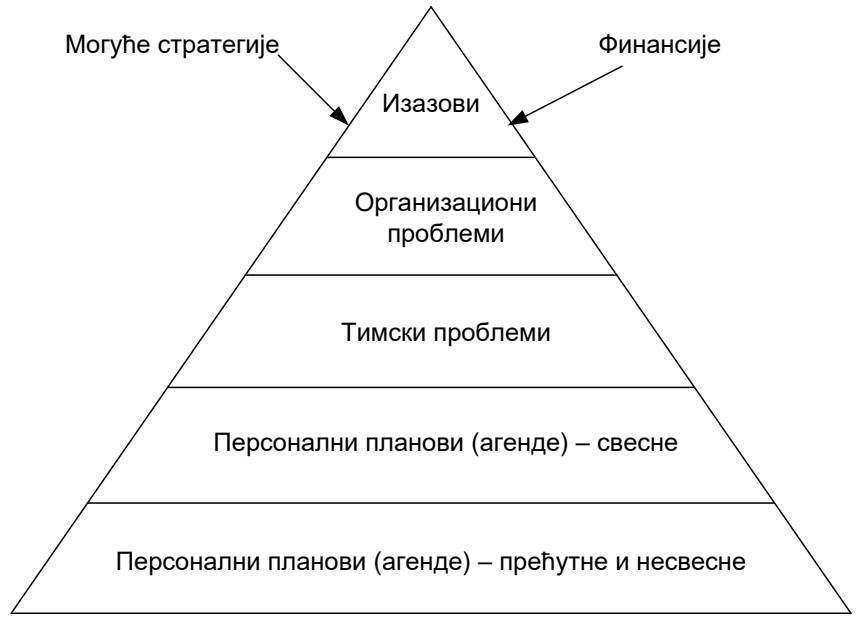

Невидљиви покретачи и стрепње него оних свесних. Рад у тиму доводи до проблема уклапања личних стилова, амбиција и циљева. На то се додају организациони проблеми везани за процедуре, начин одлучивања, односе моћи, овлашћења и други везани за организацију. На врху пирамиде су проблеми понашања везани за изазове који са собом носе стрес, креацију и ризик.

Из стратешког размишљања проистичу стратешке одлуке.

Слика 1: Бихејвиорална пирамида 5

Да би се донеле стратешке одлуке, није довољно само стратешки размишљати, потребно је размотрити могуће опције и ресурсе и на основу њих планирати акције. Свест о ресурсима, могућим акцијама и опцијама лакше је развити уз дефинисану процедуру и уз коришћење наменских алата и техника. Описано је схематски приказано на слици 2.

5 Tony Grundy, Laura Brown, Be your own Strategy Consultant, Thomson Learning, London, 2004, p. 143. 


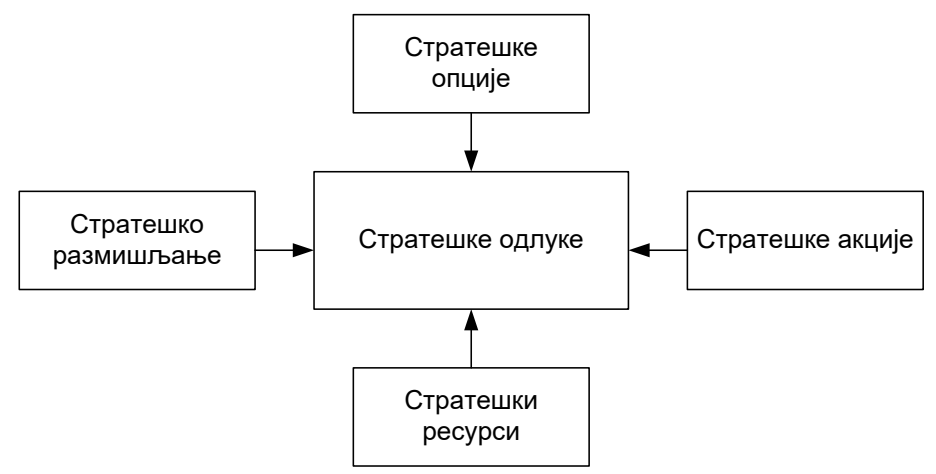

Слика 2: Доношење стратешких одлука

\section{Стратегијско мишљење и стратегијско планирање}

Стратегијско мишљење је део процеса стратегијског планирања. Оно је уткано у сваку од активности (корак) процедуре стратегијских планирања приказаних на слици 3.

Слика 3: Процедура стратегијског планирања

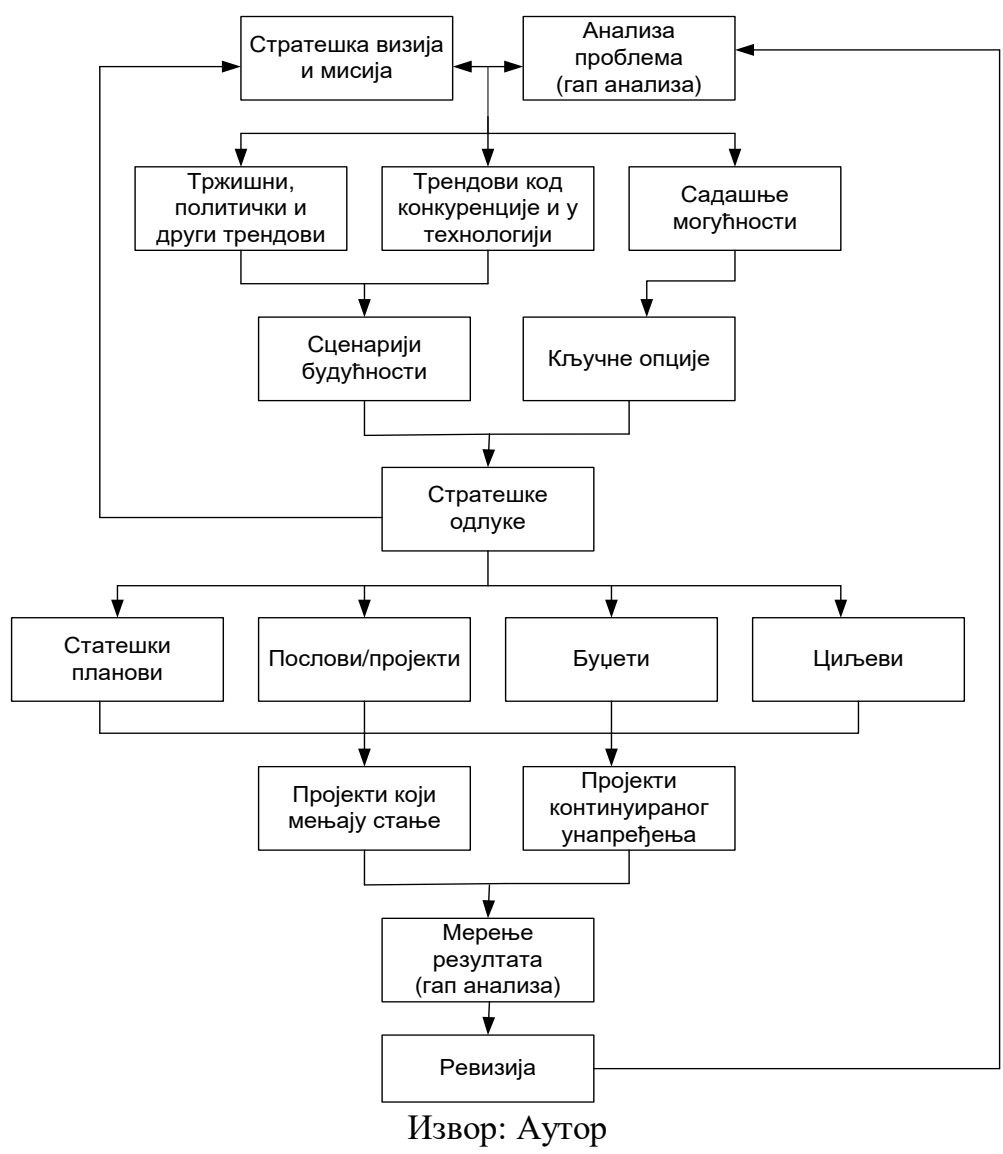

${ }^{6}$ Ibid. 
Ова процедура започиње дефинисањем визије и мисије и анализом проблема. Визија и мисија се могу одредити пре анализе проблема организације (гап анализе), у ком случају је она заснована више на жељама или захтевима стејкхолдера. Визија и мисија организације могу се одредити и на основу анализе и специфичних процедура, од којих ће једна бити описана у наставку.

Најчешћи случај је да се процеси осмишљавања визије и мисије одвијају паралелно са анализом, јер се ова два процеса у суштини преплићу. Без ослонца на анализу, визија и мисија могу бити нереалне, али то не значи да резултати анализе треба да спрече креативност у осмишљавању визије и мисије. Примена метода и алата стратегијског мишљења и доношење јасно кристалисање могућих стратешких одлука могу повратно утицати на то да се коригују или допуне визија и мисија.

Стратегија мора узети у обзир трендове, али их мора сагледавати у односу на сопствене, реалне могућности. На пример, ако би визија била да нека земља може и мора сама да чува своје небо, то би данас подразумевало да хитно започне са разматрањем могућности увођења авиона VI генерације (то је тренд), који би требао у оперативну употребу да уђе 2035-2040. године7, или неких других могућности, зависно од свог геополитичког положаја и могућих безбедносних ризика. Анализа би требала да покаже колико та земља има могућности и са чиме располаже у садашњости. Сценарији будућности би требало да покажу колико је потреба за новим авионом реална и велика. Опције могу бити разне, на пример, Француска и Немачка ће авион развијати заједно ${ }^{8}$, док ће Србија можда морати прво да купи одређени број Рафал авиона, да би била укључена у програм, јер је Марсел Дасо водећа компанија која развија нови авион, а производи Рафал. Опције куповине и финансирања, између осталог, могу бити лизинг, кредит или офсет уговор (подразумева да продавац војног материјала инвестира у земљу купца, омогући јој учешће у производњи делова или слично).

Потом долази дефинисање конкретних циљева, доношење одлука, израда планова, буџета, дефинисање пројеката. Уколико се жели непрекидно побољшавање, потребно је мерити резултате, ревидирати донете одлуке и акције и на основу научених лекција сваки следећи пут подизати ефикасност и ефективност.

\footnotetext{
${ }^{7}$ Roblin, Sebastien, „Beyond the F-22 or F-35: What Will the Sixth-Generation Jet Fighter Look Like?", The National Interest, 21 July 2018. Retrieved from:

https://nationalinterest.org/blog/buzz/beyond-f-22-or-f-35-what-will-sixth-generation-jetfighter-look-26451 (15/08/2020)

8 Schulte, Sebastian, "France, Germany to develop joint combat aircraft", IHS Jane's Defence Weekly, 2017. Retrieved from: https://web.archive.org/web/20180614230347/http://www.janes.com/article/72286/franc e-germany-to-develop-joint-combat-aircraft (15/07/2020)
} 


\section{МЕТОДЕ И ТЕХНИКЕ СТРАТЕГИЈСКОГ МИШЉЕЊА}

Постоји више метода и техника које се могу употребити ради унапређења стратегијског мишљења. Различите методе и технике се могу користити за потребе решавања различитих активности (корака) стратегијског планирања.

Слика 4: Методе и технике стратегијског мишљења

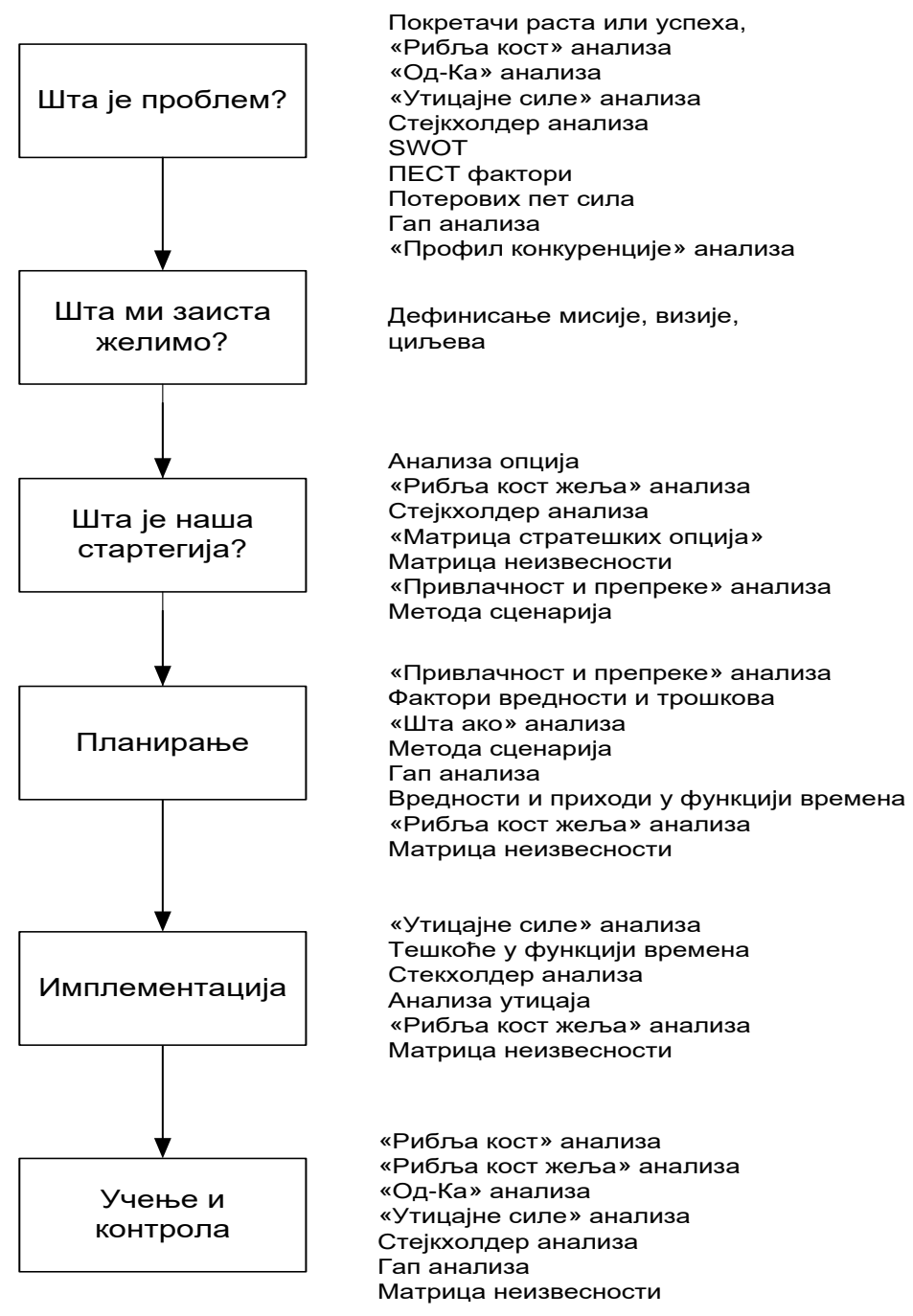

На слици 4. поред сваког садржајног корака процедуре планирања дате су методе и технике које су прикладне. Неке од њих су применљиве за више активности стратегијског планирања. Поред овде наведених метода и техника могу се користити и друге, посебно методе и технике финансијске или инвестиционе анализе. Историјске, географске, геополитичке, тржишне, пословне и сличне анализе могу, такође, бити од користи. У наставку ће бити кратко обрађене најшире применљиве методе и технике. Неке као што је SWOT анализа неће бити објашњаване из разлога што су широко познате. Пажња ће се сконцентрисати на оне најприменљивије и мање познате, као што је TOWS матрица, односно „обрнути SWOT".

Извор: Аутор

\section{ГАП (Бенчмаркинг) анализа}

Гап или Бенчмаркинг ${ }^{9}$ анализа представља процес којим се мере оперативне перформансе (димензије) компаније, фабрике, постројења, организације, па чак и појединог запосленог..., и упоређују са другим, истим или сличним субјектима.

\footnotetext{
${ }^{9}$ Најближи превод појма по значењу би био „циљно упоређивање“.
} 
Бенчмаркинг није осмишљен као иницијатива за покретање „смањења“ трошкова, већ је замишљен као иницијатива за подстицај остваривању „додатне вредности“ у свим областима у којима се примењује. Данас је то један од темеља корпоративне стратегије и планирања и заснива се на прикупљању података (снимању стања путем упитника, анкета, мерењем, оцењивањем, преузимањем из постојећих база и сл.) као првом кораку ка сваковрсним побољшањима.

Прикупљени подаци се обрађују да би се претворили у кључне показатеље успешности или перформанси (КПИ). КПИ су вредности показатеља значајних за пословање.

Одређени (израчунати) КПИ су основа за упоређивање са истим таквим показатељима из окружења (друге државе, компаније, фабрике, делатности, процеси и сл.).

Овим се утврђује разлика између жељених и достигнутих вредности КПИ, односно одређује постојећи јаз (gap). Тиме се омогућава дубља анализа предности, слабости, могућности и прилика да се побољшају и мери напредак перформанси пословања (функционисања).

O бенчмаркингу и кључним показатељима успешности видети више у литератури ${ }^{10}$. Претходно је илустровано на слици 5 . Показатељи (КПИ) се мере да би се утврдила разлика од жељеног стања.

Као додатак ГАП (Бенчмаркинг) анализи може се користити „Од - Ка“ анализа. Овде је потребно дефинисати димензије (перформансе) организације које желимо променити. Постигнуће од садашњег стања до неког будућег може се мерити нпр. оценама од 1 до 5. Тако би оцена 3 значила да је процес промена негде на пола пута, а 5 да је окончан. Обично се приказује у виду матрице са димензијама перформансе - оцене.

Слика 5: Гап анализа (Бенчмаркинг) као процес

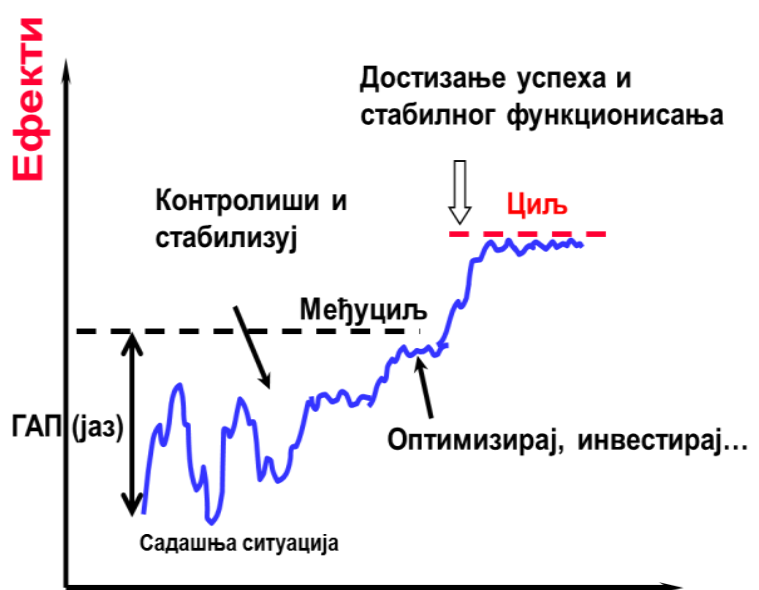

Bреме

Извор: Материјали пројекта „NIS - SHELL Opportunity Confirmation Program \& Business Improvement Program", 2006-2008.
Жељено стање може бити описано коначним или међуциљевима. Посматрано у времену, величина одступања од жељених вредности може јако варирати и у позитивном и у негативном смеру. Оно што је важно је да се мора поседовати свест о томе, а то може да се оствари само кроз бенчмаркинг, који опет мора бити непрекидан (редован) у времену. Чак и када се достигну жељени параметри, мора се радити на њиховој трајној стабилизацији.

10 Горан Мандић, Петар Станојевић, Корпоративна безбедност, Универзитет у Београду, Факултет безбедности, Београд, 2020, стр. 438-442. 


\section{Покретачи раста}

Сликом 6. приказана је техника „покретачи раста“. Она је у бити квалитативна, и намењена је томе да се наброје сви фактори који позитивно или негативно утичу на неку организацију. Структурирана је тако да се изнад хоризонталне линије наводе фактори који утичу на раст и развој организације, а испод, они који представљају препреке расту. Дужина појединих линија требала би да одговара њиховом релативном утицају или важности. На овај начин се постиже да се сагледају сви позитивни и негативни фактори и њихов релативни утицај. Може послужити и за приоритизацију активности на основу релативног утицаја фактора. На слици 6. приказана је примена технике „покретачи раста“ на примеру конципирања стратегије НИС (део Промет), чији је састављач овог текста, такође био аутор ${ }^{11}$.

Исти приказ се користи код више сличних врста анализа као што су: „анализа утицајних сила“, када се разматра однос сила које нешто омогућавају и оних које то спречавају; мотивишућих и демотивишућих фактора; повољних утицаја на будућу продају и препрека; привлачности и препрека; Потерових пет сила. Може се користити и као део SWOT анализе, када се у однос поставе могућности и претње, а потом и јаке и слабе стране организације.

Слика 6: Техника „покретачи раста“

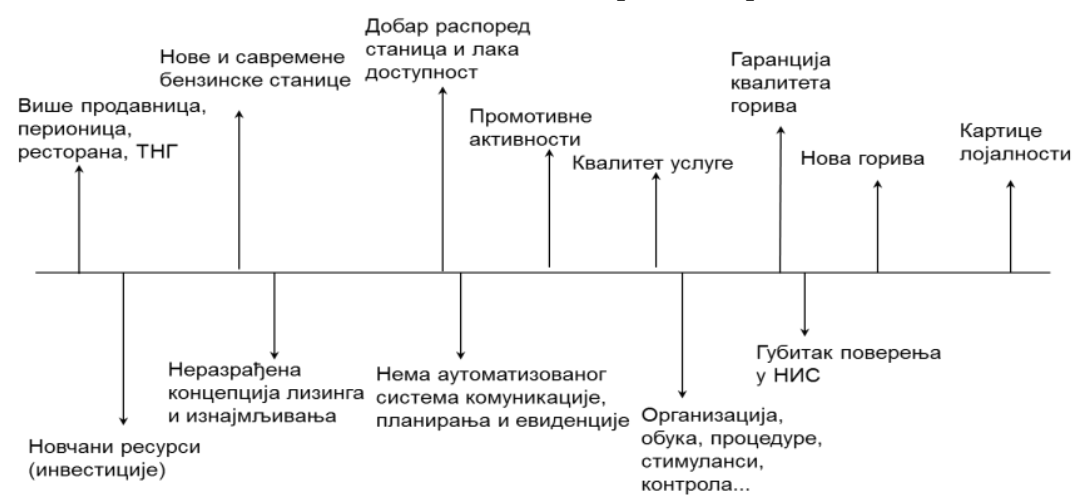

Извор: Петар Станојевић, Материјал „Стратегија НИС Промет“, Београд, 2010.

\section{Мрежни прикази и „поглед из хеликоптера (из висине)“}

Мрежни приказ је дат на слици 7. У суштини представља графикон са четири крака (крстолики), од којих сваки крак има сопствени смер који имплицира раст у позитивном или негативном смеру. Замисао је да се прикажу супротности, али дводимензионално, у односу на две величине. На пример, висока у односу на ниску неизвесност, велики утицај у односу на мали, врло вероватно у односу на мало вероватно и сличне комбинације приказане на слици 7. На слици 7 је дато 6 парова комбинација. У пракси се може користити само два пара истовремено, али

11 Петар Станојевић, Материјал „Стратегија НИС Промет“, Београд, 2010. 
се ових мрежних приказа може креирати колико год је потребно да би се испитале све комбинације фактора. У приказаном случају (за који су обележене тачке) коришћен је однос веома важно - мала важност и врло вероватно - врло невероватно, односно испитивана је вероватноћа да се остваре тврдње или претпоставке које имају различиту важност и вероватноћу за остваривање могуће стратегије компаније (ова конкретна мрежа зове се још „Матрица неизвесности“). Што је положај тачке даље у правцу краја крака сматра се да је то ближе максималној вредности фактора који је одређиван (нпр. тачка 11 има већу важност од тачке 12 на слици, а тачка 10 мању вероватноћу од тачке 11). Тачке представљају обично тврдње које се односе на будућност, стејкхолдере, тржиште, пословање, претпоставке или слично. Мреже имају за циљ да одреде њихову релативну важност, а тиме и приоритете у поступању.

Слично се могу структурирати на пример, жеље или тежње стејкхолдера и тако направити структура њихових тежњи по важности за неку организацију. Мреже које се користе за анализу стејходлера су обично са краковима велики - мали интерес и велика - мала моћ (или утицај). Тачке са бројевима у том случају представљају конкретне стејкохлдере (на пример, владу, стране земље, банке, компаније, појединце и слично). Тачке на слици 7. у реалности су представљале закључке, претпоставке или тврдње из „Хеликоптерске перспектива“ анализе за НИС Промет стратегију.

\section{Слика 7: Мрежни прикази}

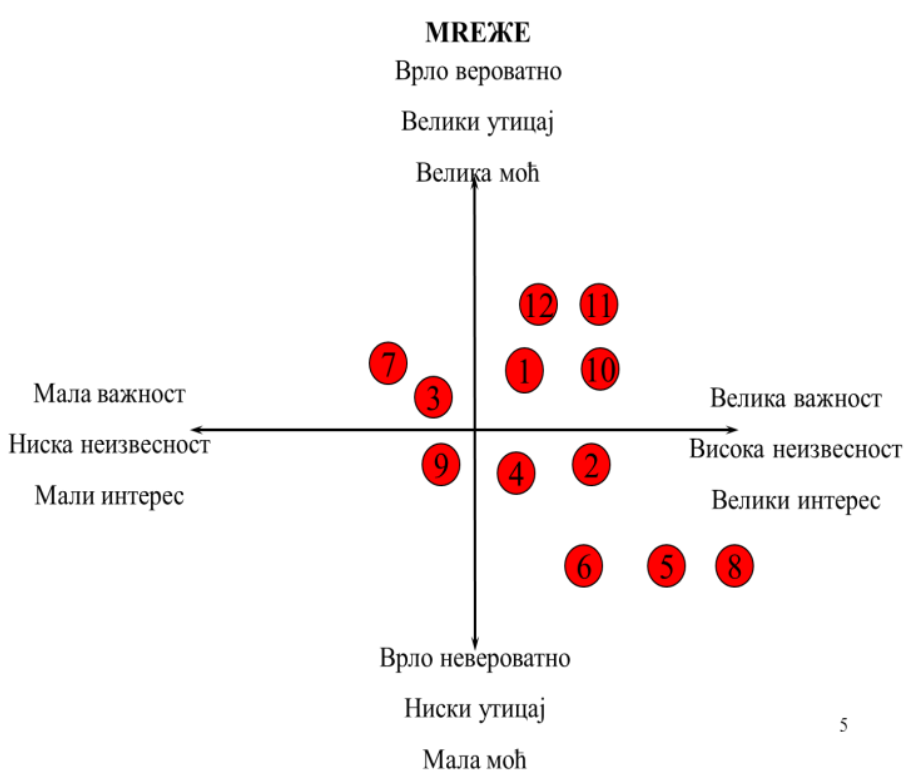

Кружићи п представљају одређене тврдње у вези раста тржишта, недостатка одређених роба, реализације пројеката и слично, за шта се сматра да може утицати на будућу компанијску стратегију (коришћена је мрежа вероватно-важност). Ове тврдње су срочене (дефинисане) на основу ширег, односно из више аспеката сагледавања стварности и будућих догађаја, па се зато називају „поглед из хеликоптера или са висине".

Извор: Петар Станојевић, Материјал „Стратегија НИС Промет“, Београд, 2010. 


\section{ПЕСТ анализа}

Назив ПЕСТ анализе потиче од почетних слова енглеских речи за политичке, економске, технолошке и социјалне факторе. Њоме се доводе у везу фактори који највише могу утицати на организацију. Међусобни утицај ових фактора дат је на слици 8.

Слика 8: ПЕСТ Анализа

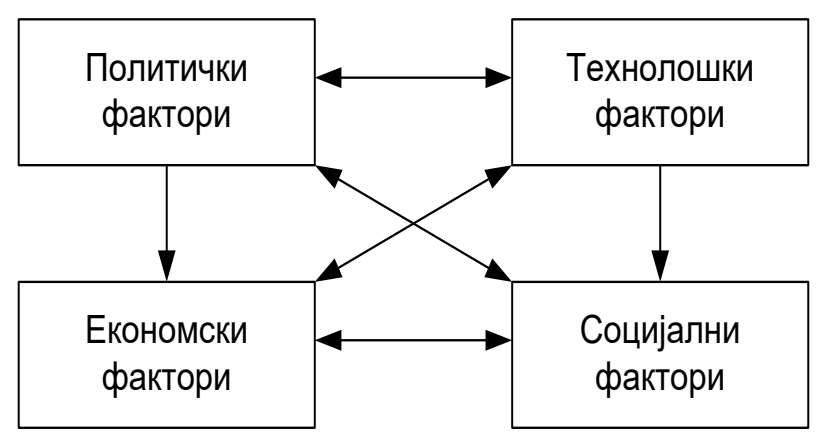

Политички обухватају стејкохлдере, регулативни оквир, односе моћи изван, али и у компанији и сл. Економски подразумевају макроекономска кретања, порезе, државне и друге подстицаје, цене енергената и главних улазних материјала и сл.

Извор: Tony Grundy, Laura Brown, Be your own Strategy Consultant,

Thomson Learning, London, 2004, p. 143.

Социјални фактори подразумевају бригу за сигурност радних места, зараде и порезе на зараду, социјална осигурања и слично. Технолошки фактори утичу на ефективност и ефикасност рада, али и на пренос и обраду информација. ПЕСТ анализа служи за анализу окружења организације, анализу могућих сценарија, одређивање фактора критичних за успех и за дефинисање могућих опција.

\section{Профилисање и анализа конкуренције}

У фази дефинисања проблема неопходно је извршити анализу конкуренције. Један једноставни табеларни алат је дат у табели 2, где се оцењују особине конкурентских активности. Под конкурентима се могу сматрати и стране војске, не само компаније. Ове табеле могу бити и другачије у зависности од карактера конкуренције и могућности. И поред делимичне квантификације у суштини се ради о квалитативној оцени. Важно је да се по завршетку анализе може направити што објективније поређење, како по појединим карактеристикама, тако и укупно (збирно). Разматране карактеристике могу имати и тежинске коефицијенте, уколико се жели нешто напреднија квантификација. У примеру датом у табели 2 то се чини множењем вредности редова и колона. На пример, ако је оцењено да је бренд конкуренције средњи, а тежина бренда је 3, онда је резултат $3 \times 3=9$.

Табела 2: Анализа конкуренције

\begin{tabular}{|l|l|l|l|l|l|}
\hline & Веома јак (5) & Јак (4) & Средњи (3) & Слаб (2) & Врло слаб (1) \\
\hline Бренд (3) & & & 9 & & \\
\hline $\begin{array}{l}\text { Перформансе производа } \\
\text { (5) }\end{array}$ & & 20 & & & \\
\hline Квалитет услуге (2) & & & & 4 & \\
\hline
\end{tabular}




\begin{tabular}{|l|c|c|c|c|c|}
\hline & Веома јак (5) & Јак (4) & Средњи (3) & Слаб (2) & Врло слаб (1) \\
\hline Иновативност (2) & & & & 4 & \\
\hline Трошкови / цена (4) & & 16 & & & \\
\hline Системи подршке (1) & & & & & 1 \\
\hline Знања и вештине (2) & 10 & & & & \\
\hline
\end{tabular}

Извор: Аутор

\section{Атрактивност идеја, прочзвода, тржишта...}

За овакве врсте анализа користи се комбинација метода и то: ПЕСТ анализа, Покретачи раста, техника „Потерових пет сила (конкуренције)“ и Џенрал Електрик мрежа. Ова последња дата је на слици 9. Техника „Потерових пет сила“ користи се као подсетник томе које све факторе треба узети у обзир при анализи тржишта. Добар пример за примену ове технике је тржиште нафте. Уколико је производња нафте у свету већа од потражње, онда је моћ преговарања у рукама купаца који могу да бирају од кога ће куповати. Ако је потражња већа од производње, онда снабдевачи могу да бирају коме ће продати. Нова нафтна или гасна открића у свету представљају нове потенцијалне конкуренте. Електрични аутомобили су пример замене. За исту сврху Џенерал Електрик је развио специфичну технику, где се помоћу мреже са подељцима слабо, средње, јако у однос стављају тржишна атрактивност, покретачи раста или споменутих пет сила са сопственим или конкурентским могућностима (слика 10). Мрежа омогућава стављање истраживаних чињеница у релативни однос. Циљ примене мреже је пословно позиционирање, истраживање нових могућности, разумевање инвестиционих захтева или вредности за купца.

Слика 9: Техника „Потерових пет сила“

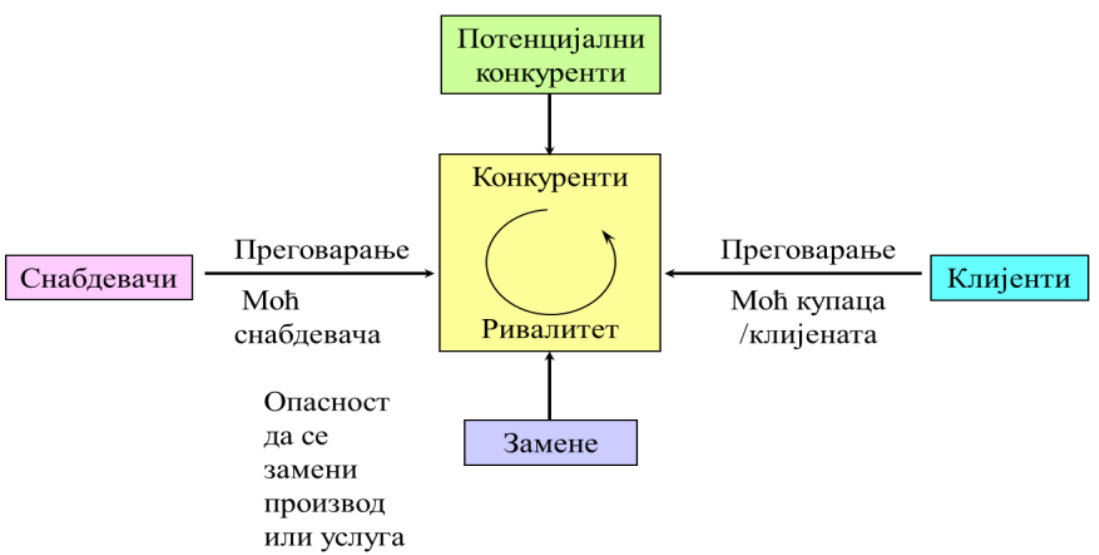

Извор: Tony Grundy, Laura Brown, Be your own Strategy Consultant,

Thomson Learning, London, 2004, p. 143. 
Слика 10: Џенерал Електрик мрежа

СТРАТЕШКО ПОЗИЦИОНИРАњЕ: ПОСТОЈЕЋЕ И НОВЕ ПОСЛОВНЕ ИДЕЈЕ - „ШЕНЕРАЛ ЕЛЕКТРИК МРЕЖА“

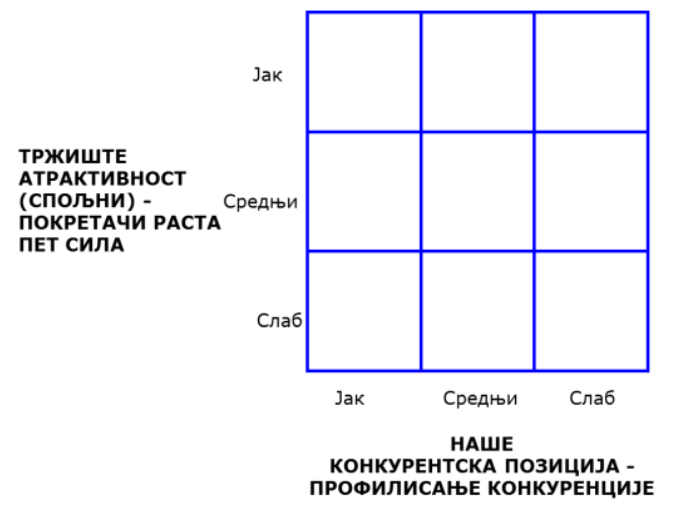

Извор: Tony Grundy, Laura Brown, Be your own Strategy Consultant, Thomson Learning, London, 2004, p. 143.

\section{„Рибља кост“ анализа}

Анализа која се служи графичким приказом рибље кости може имати две намене. Прва је да се прикажу фактори који утичу на неки процес (који се графички приказује са кичменом кости, а назив (или симптом) му се пише на десној страни) и тада се зове анализа „рибље кости“ (кости у тада усмерене улево). Слична је анализа „рибља-кост жеља“, само се овде не разматра конкретни процес већ визија организације и акције или фактори који могу довести до њеног остварења. Пример „рибља-кост жеља“ анализе за НИС Промет је дат на слици 11. Приказане су акције или мере које би требало да доведу до остварења визије организације.

Слика 11: Анализа „рибља-кост жеља“

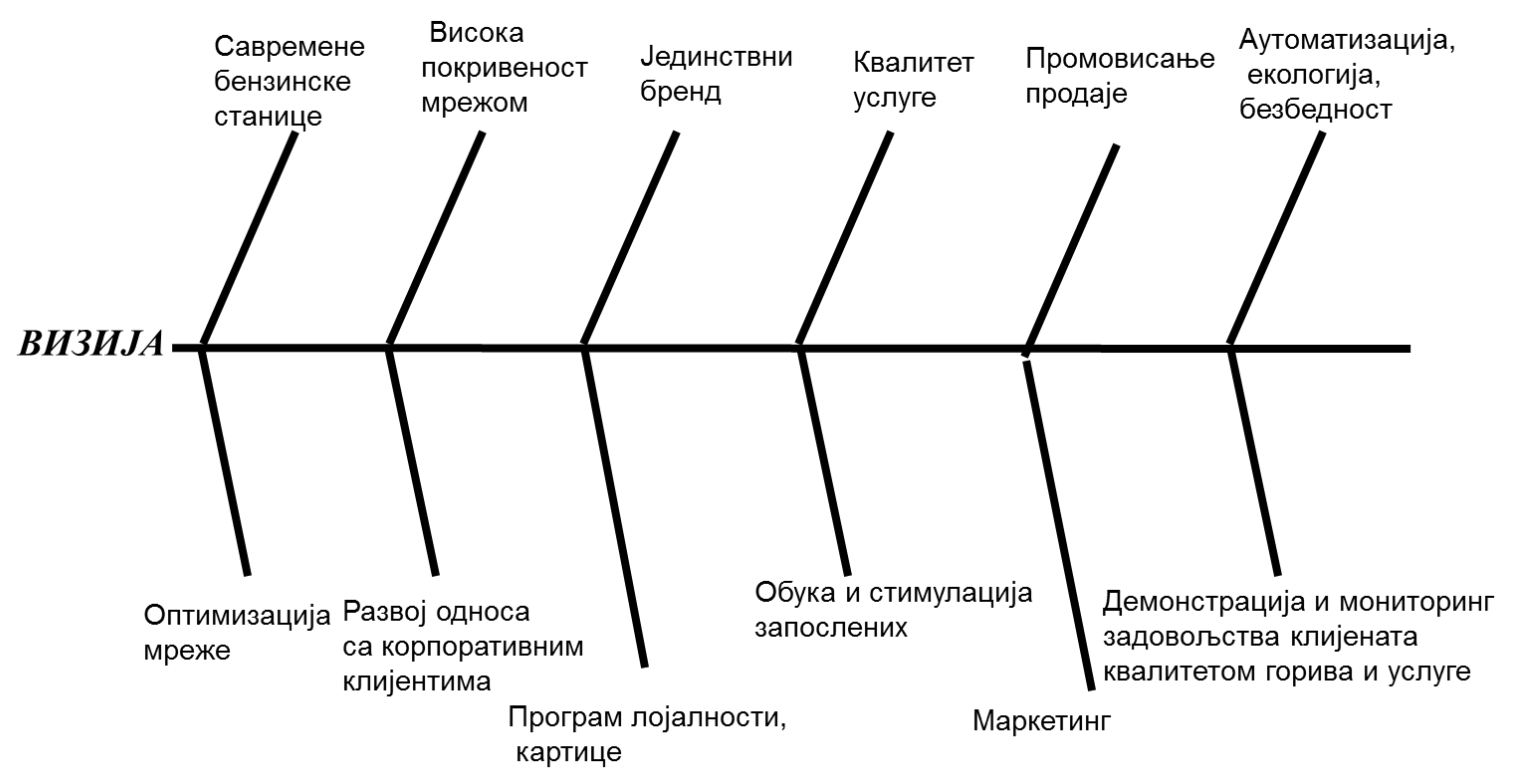

Извор: Петар Станојевић, Материјал „Стратегија НИС Промет“, Београд, 2010. 


\section{Методе сценарија и симулације}

Симулација је метода за одређивање перцепције о алтернативним окружењима у будућности на које данашње одлуке могу утицати. Планирање сценарија је приступ „споља ка унутра“ стратешком менаџменту. Ова методологија настала је пре око сто година у војсци и за потребе ратних игара, међутим, тек је у последњих 30 година ушла у ширу примену. Поред тога, има изузетно широку примену у скоро свим областима. Развој рачунарске технике је омогућио практичну примену ове методе и даљим развојем пружа све веће могућности примене. Њоме се може експериментисати са моделима који описују понашање сложеног система у времену. Испитивање унутрашњих међузависности елемената система, процена понашања у одређеним ситуацијама, провера нових стратегија и других показатеља могућа је под условом да је креиран добар симулациони модел. Симулирају се увек неки могући сценарији, односно редоследи могућих догађаја.

Планирање сценарија не значи прогнозирање будућности већ сагледавање свих могућности и помагање организацијама да постану проактивне у управљању својом будућношћу. Тиче се употребе и коришћења информација које су већ познате у организацији, али које се допуњују екстерним нетрадициналним схватањима са циљем усвајања наученог оквира за будућност.

Процес планирања сценарија има више корака:

1. Идентификовање покретачких сила које се заснивају на друштвеним, техничким, економским, политичким и правним покретачима и покретачима који се односе на животну средину и сл.;

2. Идентификовање екстремних величина (мин - макс) у односу на сваку покретачку силу;

3. Скупљање података у кластере, прављење анализе покретачких сила;

4. Одређивање утицаја и неизвесности;

5. Одређивање оквира, могућег редоследа и обима сценарија;

6. Дефинисање сценарија.

Дефинисање сценарија обично иде кроз међусобно повезивање догађаја уз одређену временску секвенцу. Догађаји се могу повезати међу собом на основу одређених правила. Вредности које поједини параметри добијају последице су дефинисаних правила. Квалитетни сценарији и симулациони модели раде се у сарадњи аналитичара реалних система и стручњака за симулационе системе. Основни критеријуми за оцену ваљаности симулационих модела јесу техничка ваљаност, операциона ваљаност и динамичка ваљаност модела. Примена ове методе се толико раширила да се практично свакодневно сусрећемо са њом у животу, почев од игрица за децу, па до симулатора за обуку пилота. Управљачке симулационе игре најчешће се раде ради провере одређених организационих решења, стратегија или „конкурентске борбе на тржишту“. 


\section{ФОРМИРАЊЕ ПОЖЕЉНЕ ВИЗИЈЕ И ЦИЉЕВА}

Сматра се да визија организације одговара на питање: „Шта желимо да постанемо?“, док мисија одговара на питање: „Која је наша сврха и главна делатност или услуга?“. Визија представља могуће и пожељно будуће стање једне организације. Мисија је више везана за понашање и садашњост. Из визије проистичу циљеви чијим се достизањем она ефективно остварује. Мисија као садашње стање може се одредити методама анализе о којима је овде било речи и неће се шире образлагати.

Обично се мисли да је одређивање визије и циљева неке организације ствар логике и креативности највишег руководства. Ово често доводи до исказа који су или нереални, или преписани, или неповезани са стварношћу или неразумљиви. Циљ је сачинити такву визију која ће бити подстицајна и истовремено јасно указивати свима шта треба чинити. Визија Шел је 2006. године гласила: „Више производње, профитабилна прерада и продаја“.12 За „нафташе“ то је више него јасно, треба обезбедити што више производње нафте, јер се ту крије највећи профит, и истовремено нафту прерадити и продати, а не изгубити већ зарадити, јер је ту конкуренција најжешћа.

Постоје и развијене методологије чијим се спровођењем долази до формирања пожељних визија. Једна од њих је развијана у оквиру пројекта NIS - SHELL Opportunity Confirmation Program \& Business Improvement Program, у коме је аутор овог рада учествовао у улози руководиоца пројекта са стране НИС $^{13}$.

Наведена методологија формирања визије састоји се од више корака:

1. Преглед тренутне стратегије организације;

2. Гап (Бенчмаркинг) анализа;

3. Стејкхолдер анализа;

4. Унутрашњи утицаји и неизвесности;

5. Мапирање компетенције;

6. Анализа утицајних сила (предности и мана организације);

7. Планирање сценарија - симулација;

8. SWOT/TOWS матрице;

9. Дефинисање визије;

10. Тестирање визије анализом заинтересованих страна;

11. Одређивање наредних акција.

Све кораке ове методологије морају прорадити највиши менаџери, тимски, уз конструктивну борбу мишљења и позитиван став, да се до крајњег циља мора доћи заједнички, пожељно консензусом. Први корак подразумева анализу тренутне стратегије, њених постигнућа и недостатака. Потом се анализира

12 „More upstream, profitable downstream“. Постоји и дужа верзија ове визије.

13 Материјали пројекта „NIS - SHELL Opportunity Confirmation Program \& Business Improvement Program", 2006-2008. 
резултат Гап (Бенчмаркинг) анализе како би се уочили актуелни недостаци, који имају или могу имати последице по функционисање. Пажња се посебно обраћа на највећа одступања од пожељних вредности, траже се њихови узроци и начини превазилажења.

Наредни корак је стејкоходлер анализа која се спроводи помоћу мреже дате на слици 7 са димензијама велики - мали интерес и велика - мала моћ (или утицај). Затим се спроводи анализа унутрашњих утицаја и неизвесности коришћењем мреже са слике 7 уз димензије велика - мала извесност и велики - мали утицај. Конкуренција се мапира на начин приказан у табели 2. и/или помоћу „Џенерал Електрик“ мреже са слике 10. Анализа утицајних сила (предности и мана организације) се врши на основама технике „покретачи раста“ приказане на слици 6. Пожељно је направити и анализе више сценарија и потребне симулације.

На основу свега претходног менаџмент израђује SWOT анализу. Ова анализа одвојено посматра предности, мане, могућности и ризике једне организације. Да би се у међусобни однос довеле ове димензије организације користи се TOWS матрица, или обрнути SWOT. TOWS матрица дата је на слици 12.

Слика 12: TOWS матрица

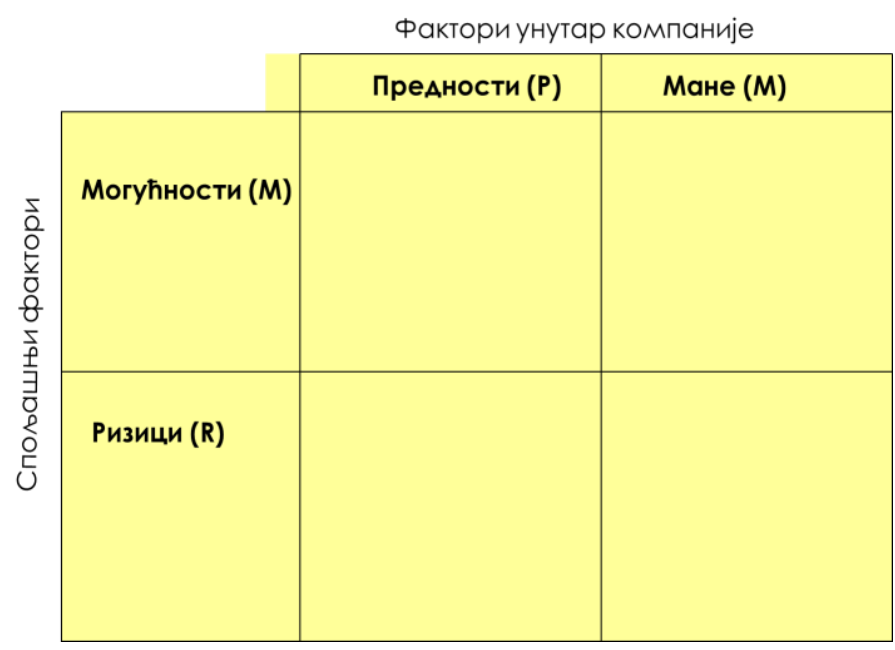

Извор: Адаптација аутора
Помоћу овог алата могуће је направити анализу парова могућности - предности, могућности - мане, ризици предности, ризици - мане и на тај начин добити детаљнији и свеобухватнији увид у организацију. На пример интересанто је утврдити које то предности организације са собом носе ризике, да ли су све предности уједно и могућности или које могућности могу представљати мане.

Након примене свих претходно наведених метода и алата може се приступити дефинисању визије организације. Ради олакшавања овог процеса конципирано је неколико помоћних тврдњи:

- Тврдња - везано за очекивања у смислу пословања: „Ми ћемо (циљеви/могућности) ..."

- Тврдња - везано за посао пред нама: „Посао ће од нас захтевати да наставимо са јачањем постојећих способности (предности)....“

- Тврдња - везано за побољшања: „Да би смо побољшали наше пословање, урадићемо (могућности/ризици)...”

- Тврдња - везано за предности које поседује организација: „Да би смо осигурали овако пословање, побољшаћемо следеће предности..." 
- Тврдња - везано за људске ресурсе: „Да бисмо развили већу мотивисаност и ниво образовања код својих радника, наставићемо да / или ћемо побољшати своје способности и предности у управљању средствима у (предности/мане)...”

На пример, као једна од могућих визија НИС 2006. године ${ }^{14}$ срочено је (парафразирано): „Одговорним понашањем преко коришћења предности наше логистике, приступа усмереног на очување животне средине и образовањем радне снаге, достићи ћемо наше главне циљеве. Повећаћемо удео на тржишту, побољшаћемо марже и осигурати дугорочну профитабилност уз помоћ трајног развојног модела. Повећаћемо напоре у побољшању и управљању безбедношћу и заштитом на раду, добијању сертификата ЕУ, брендирању и маркетингу и оперативној изврсности. Направићемо организациони и мотивациони модел који ће се заснивати на најбољој пословној пракси“. Из визије проистичу циљеви који се требају остварити. Пример циљева везаних за продају дела НИС Промет је дан у табели 3.

Табела 3: Циљеви продаје НИС Промет

\begin{tabular}{|c|c|}
\hline НИС Промет & 2012. година \\
\hline Учешће на тржишту \% & Не мање од $34 \%$ \\
\hline Просечна продаја по објекту, тона на & Не мање од 5,7 (раст од \\
дан & $50 \%)$ \\
\hline Обим малопродаје, хиљада тона & 850 (раст око 30\%) \\
\hline
\end{tabular}

Извор: Аутор

\section{ИЗБОР СТРАТЕГИЈЕ}

Начелно би увек требало да буде више стратегијских опција, или барем више подваријанти једне „главне“ опције. Уколико постоји само једна опција, вероватно се организација налази у стању озбиљне кризе. Генерисање опција је задатак највишег менаџмента, који у овом случају мора радити као и у случају креирања визије и циљева. Да би се дефинисале могуће опције погодно је користити алате попут „Стратегијског октопода“, чији је пример приказан на слици 13.

14 Материјали пројекта „NIS - SHELL Opportunity Confirmation Program \& Business Improvement Program", 2006-2008. 
Слика 13: „Октопод“ метода за генерисање стратешких опција

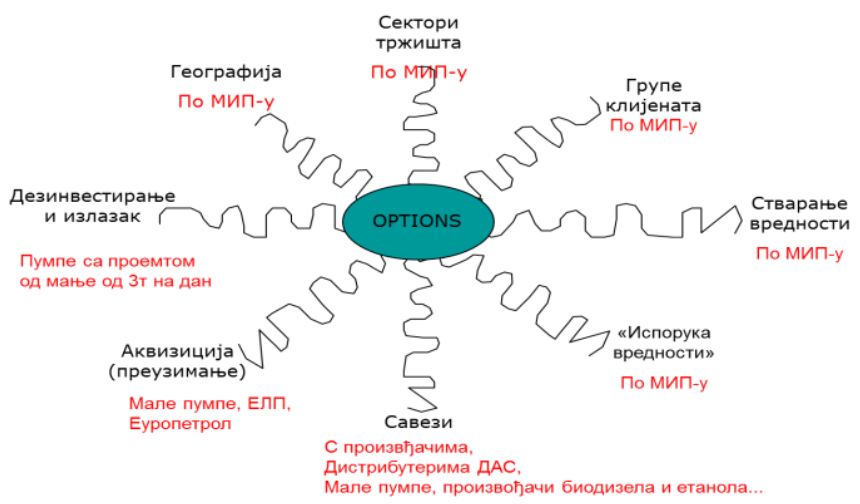

Извор: Петар Станојевић, Материјал „Стратегија НИС Промет“, Београд, 2010.

Овај алат служи да се генеришу подопције које би се могле уклопити у посебне опције. Овде је дат приказ карактеристичан за корпорације, док би за државе или војске изгледао другачије. Могуће је успоставити паралеле, као на пример: Сектори тржишта - непријатељи; Групе клијената - видови или родови војске; Стварање вредности - могућност уништења; Испорука вредности - маневар; Савези - савези; Аквизиција - заузимање територије или објеката; Излазак одустајање од политичко-војних циљева; Географија - географија.

Све генерисане опције морају бити оцењене према унапред одређеним критеријумима. Избором критеријума организација ставља будуће резултате у контекст своје визије и циљева. На слици 14. приказана је једна Матрица стратегијских опција ${ }^{15}$. У колонама су дате стратегијске опције, а у редовима изабрани критеријуми. У ћелијама пресека опција и критеријума знаковима је дата квантификација сваке од опција у односу на усвојене критеријуме (условна квантификација). Поређењем броја придружених знакова по опцијама може се направити избор између опција (највише знакова - најбоље).

Слика 14: Матрица стратегијских опција

\begin{tabular}{|c|c|c|c|c|c|}
\hline Критеријуми & мип 1 & мип 2 & мип 3 & $\begin{array}{l}\text { Дефанзивна } \\
\text { варијанта } \\
\text { развоја }\end{array}$ & \begin{tabular}{|l|} 
Офанзивна \\
варијанта развоја
\end{tabular} \\
\hline $\begin{array}{l}\text { СТРАТЕГИЈСКА } \\
\text { АТРАКТИВНОСТ }\end{array}$ & $\downarrow$ & $\downarrow \downarrow$ & $\downarrow \downarrow \downarrow$ & $\downarrow$ & $\downarrow \downarrow \downarrow$ \\
\hline $\begin{array}{l}\text { ФИНАНСИІКА } \\
\text { АТРАКТИВНОСТ }\end{array}$ & $?$ & $?$ & $?$ & $?$ & $?$ \\
\hline $\begin{array}{l}\text { ТЕЖИНА } \\
\text { ИМПЛЕМЕНТАЦИЈ } \\
\text { Е }\end{array}$ & $\downarrow \downarrow \downarrow$ & $\downarrow$ & $\downarrow$ & $\downarrow$ & $\downarrow$ \\
\hline $\begin{array}{l}\text { НЕИЗВЕСНОСТ И } \\
\text { РИЗИК }\end{array}$ & $\downarrow$ & $\downarrow$ & $\downarrow$ & $\downarrow$ & 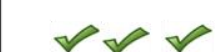 \\
\hline $\begin{array}{l}\text { ПРОХВАТЉИВОСТ } \\
\text { ЗА СТЕЛКХОЛДЕРЕ }\end{array}$ & $\downarrow$ & $\nabla_{\downarrow}$ & $\downarrow$ & $\downarrow$ & $\downarrow$ \\
\hline
\end{tabular}

Извор: Петар Станојевић, Материјал „Стратегија НИС Промет“, Београд, 2010.

15 Петар Станојевић, Материјал „Стратегија НИС Промет“, Београд, 2010. 
Као што је већ речено, приликом избора коначне опције, односно стратегије, могу се додатно користити већ поменути алати као што су „Стејкхолдер анализа“ да би се оценило како ће они реаговати на предложено, „Матрица неизвесности“ да би се оценила вероватноћа или ризици успеха или неуспеха, „Привлачност и препреке“ и друге које су наведене на слици 4 као оне које помажу доношењу коначне одлуке о стратегији.

\section{ПЛАНИРАЊЕ, ИМПЛЕМЕНТАЦИЈА, УЧЕЊЕ И КОНТРОЛА}

Методе планирања су релативно добро познате и овде се неће шире образлагати, али се мора нагласити да се без доброг и реалног плана по свим аспектима (ресурса, времена, људи, новца и сл.) и имплементације, само усвајање стратегије обесмишљава. Имплементација се, обично, спроводи према правилима пројектног менаџмента. Као алат за одређивање акција које треба спровести код имплементације усвојене стратегије може се користити 7С модел консултантске куће Мекинзи, приказан на слици 14. Он служи да се за сваки од седам најважнијих одлика неке организације одреде активности преко којих ће се постићи циљеви и остварити визија. На слици је приказано коришћење овог модела на већ наведеном примеру НИС Петрола.

Слика 14: 7С модел Мекинзија примењен на НИС Промет ${ }^{16}$

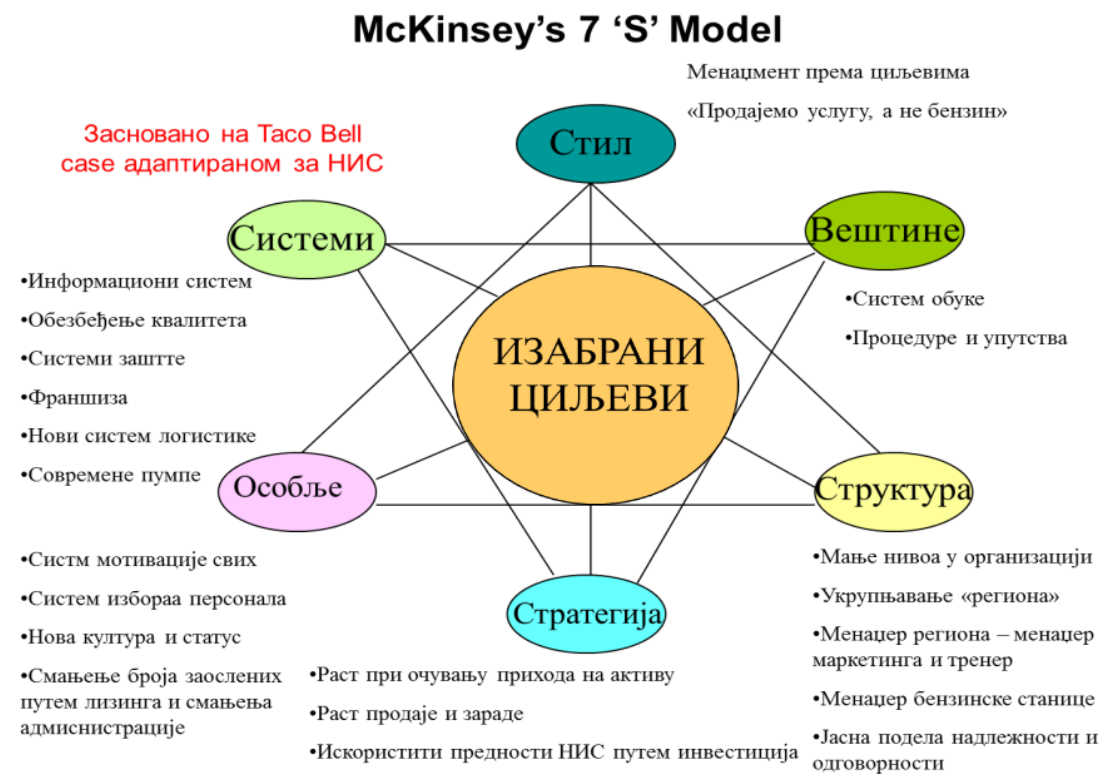

Имплементација стратегије подразумева промене. Управљање променама је неизоставни део управљања пројектом и за то постоје разрађене методологије.

16 Петар Станојевић, Материјал „Стратегија НИС Промет“, Београд, 2010. 
Циљ им је да се промене уводе на систематски начин, уз поштовање процедура и документовано, али и да се путем прилагођеног и планског начина комуникације развије разумевање, потребна знања и свест о потреби и користима промена, а затим и осећај подршке променама код оних на које се промене односе.

За подршку процесу управљања имплементацијом могу се користити алати којима се унапређује планирање тако што се одређују нпр. могући извори тешкоћа и могући тренуци њихове појаве у времену (нпр. графикон „Тешкоће у времену“) или „Матрица спремности за стратегијске промене“, „Привлачност тешкоћа имплементације“ и слично. Мерење резултата имлементације се може реализовати путем метода наведених на слици 4, од којих је свакако најважнија Гап анализа, која представља основни елемент контроле. Ово је неизоставно потребно уколико се жели стално усавршавање организације уз коришћење искустава („научене лекције“).

\section{ЗАКЉУЧНА РАЗМАТРАЊА}

Стратегијско мишљење је специфично. Чињеница је да се од стратега, на пример, одбрамбене политике и са њом повезаних програма развоја и опремања, тражи да пруже одговоре на питања која тек треба да буду постављена ${ }^{17}$. За креирање таквих стратегија није довољно само експертско знање, креативност и маштовитост појединца. То је данас задатак мултидисциплинарних тимова људи који поред свег знања и добре воље морају наћи начин да мисле у истом правцу, интегришу трендове различитих области и креирају свима разумљив резултат као плод заједничког рада. Стратегија не сме бити искључиви плод жеља, јер су силе које на њу утичу разноврсне, политичке, технолошке, људске и друге, а све заједно су повезане са неизвесношћу. ${ }^{18}$

Превазилажење наведених проблема омогућавају методе и технике стратегијског мишљења, тачније подршке стратегијском мишљењу. Алгоритими, методе и технике омогућавају хијерархијску структурираност, од политике преко стратегије до тактике, али и по потреби рад у супротном правцу.

Стратегију је тешко правилно разумети, тешко је компетентно предавати, а још је теже спроводити у дело. Али, као што историја сведочи, довољно добра стратегија и њено извршавање могу бити довољни да чак и лошији стратези победе. Стратегија генерички није лек за све болести, али кад општу теорију добро разумеју образовани практичари који је морају спровести у пракси, то максимизира изгледе за успех.

17 Colin S. Gray, Strategic Thoughts for Defense Planners, Survival, Vol. 52, No. 3, 2010, pp. 159178.

18 Colin S. Gray, Strategic Thoughts for Defense Planners, Survival, 52:3, 159-178, 2010, D0I: 10.1080/00396338.2010.494883 
Постоје развијени алгоритми примене стратегијског мишљења и планирања. Стратегијско мишљење се мора довести у контекст са стратегијским планирањем. Већина активности стратегијског планирања не може се реализовати без стратегијског осмишљавања. До данас је осмишљено и ствара се мноштво погодних поступака, метода и техника уз помоћ којих се олакшава и структурира процес стратегијског мишљења и оне могу бити од помоћи свим практичарима. Неке од метода и техника стратегијског мишљења могу се применити за више фаза или активности стратегијског планирања. Све оне имају своје предности и мане као и могућности примене.

\section{БИБЛИОГРАФИЈА}

1. Tony Grundy, Laura Brown, Be your own Strategy Consultant, Thomson Learning, London, 2004., ISBN 1-86152-980-5.

2. Roblin, Sebastien, "Beyond the F-22 or F-35: What Will the Sixth-Generation Jet Fighter Look Like?". The National Interest, 21 July 2018. https://nationalinterest.org/blog/buzz/beyond-f-22-or-f-35-what-will-sixthgeneration-jet-fighter-look-26451

3. Schulte, Sebastian, "France, Germany to develop joint combat aircraft". IHS Jane's Defence Weekly, 2017-07-13. https://web.archive.org/web/20180614230347/http://www.janes.com/article /72286/france-germany-to-develop-joint-combat-aircraft

4. Горан Мандић, Петар Станојевић, Корпоративна безбедност, Факултет безбедности, Универзитет у Београду, Београд, 2020., стр. 438-442.

5. Петар Станојевић, Материјал „Стратегија НИС Промет“, Београд, 2010.

6. Материјали пројекта „NIS - SHELL Opportunity Confirmation Program \& Business Improvement Program“, 2006-2008.

7. Colin S. Gray, Strategic Thoughts for Defense Planners, Survival, 52:3, 159-178, 2010, DOI: 10.1080/00396338.2010.494883

8. Colin S. Gray, Strategy and Defense Planning - Meeting the Challenge of Uncertainty, Oxford University Press, 2014., ISBN 978-0-19-870184-2

\section{STRATEGIC THINKING AND DECISION MAKING APPROACHES}

In this paper, attention is paid on a successful strategy creation (design) or at least on ones that have a lower risk of failure. Creating strategies requires strategic thinking, specific in nature. The aim of the paper is to give an overview of the methods and techniques of strategic thinking, more precisely strategic thinking support as well as the ways and possibilities of their application. Also, on the basis of existing ones, algorithms for the application of strategic thinking and planning have been developed. The features, ways and preconditions of strategic thinking are analyzed. Strategic thinking has been brought into context with strategic planning. Most strategic planning activities cannot be accomplished without strategic thinking. Contemporary, many convenient procedures, methods and techniques have been designed and created to facilitate and 
structure the strategic thinking process. Some of the known methods and techniques are presented in the paper through schemes, algorithms, charts or verbal descriptions. Methods and techniques are presented, mostly, based on real examples. Some of the methods and techniques of strategic thinking can be applied to multiple phases or activities of strategic planning. Their advantages and disadvantages as well as possibilities of application are analyzed. Special attention is paid to the methodology and techniques useful for defining the vision and mission of the organization.

Keywords: strategy, ancient thinking, methods, techniques 